University of Nebraska - Lincoln

DigitalCommons@University of Nebraska - Lincoln

6-1976

Five Species of Platyhelminths from Bufo marinus L. (Anura:

Bufonidae) in Colombia with Descriptions of Creptotrema lynchi

sp. n. (Digenea: Allocreadiidae) and Glypthelmins robustus sp. $\mathrm{n}$. (Digenea: Macroderoididae)

Daniel R. Brooks

University of Toronto,dnlbrooks@gmail.com

Follow this and additional works at: https://digitalcommons.unl.edu/parasitologyfacpubs

Part of the Parasitology Commons

Brooks, Daniel R., "Five Species of Platyhelminths from Bufo marinus L. (Anura: Bufonidae) in Colombia with Descriptions of Creptotrema lynchi sp. n. (Digenea: Allocreadiidae) and Glypthelmins robustus sp. $\mathrm{n}$. (Digenea: Macroderoididae)" (1976). Faculty Publications from the Harold W. Manter Laboratory of Parasitology. 216.

https://digitalcommons.unl.edu/parasitologyfacpubs/216

This Article is brought to you for free and open access by the Parasitology, Harold W. Manter Laboratory of at DigitalCommons@University of Nebraska - Lincoln. It has been accepted for inclusion in Faculty Publications from the Harold W. Manter Laboratory of Parasitology by an authorized administrator of DigitalCommons@University of Nebraska - Lincoln. 


\title{
FIVE SPECIES OF PLATYHELMINTHS FROM BUFO MARINUS L. (ANURA: BUFONIDAE) IN COLOMBIA WITH DESCRIPTIONS OF CREPTOTREMA LYNCHI SP. N. (DIGENEA: ALLOCREADIIDAE) AND GLYPTHELMINS ROBUSTUS SP. N. (DIGENEA: MACRODEROIDIDAE)*
}

\author{
Daniel R. Brooks \\ Gulf Coast Research Laboratory, P.O. Box A.G., Ocean Springs, Mississippi 39564
}

ABSTRACT: Gorgoderina diaster, Cylindrotaenia americana, and Ophiotaenia bonariensis are reported, and Creptotrema lynchi and Glypthelmins robustus described from Bufo marinus from 3 localities in the Republic of Colombia. All are new locality records and B. marinus is a new host for G. diaster and $C$. americana. Creptotrema lynchi differs from $C$. creptotrema in possessing smaller eggs, relatively smaller oral papillae and suckers, and elongate rather than spherical testes. Glypthelmins robustus differs from all other species in the genus in possessing a pharynx which is significantly larger than the acetabulum and tegumental spines restricted to the anterior fifth of the body. If further differs from G. facioi in possessing diagonal testes and slightly smaller eggs, and from G. palmipedis in possessing an I-shaped excretory vesicle and slightly smaller eggs. The known species of amphibian platyhelminths from Colombia have affinities with both North and Central as well as South America.

Twenty-seven specimens of Bufo marinus L. collected from three localities in the Republic of Colombia during June 1975 contained specimens of five species of adult platyhelminths, including two previously undescribed. Host specimens have been deposited in the University of Kansas Museum. Worms were removed from the host and examined live with the aid of a stereoscope; trematodes were flattened with negligible coverslip pressure, cestodes were relaxed in pond water; all were fixed with AFA, stored in 70\% ethanol, stained with Mayer's hematoxylin, and mounted in Canada balsam. Measurements are in micrometers unless otherwise stated; figures were drawn with the aid of a drawing tube.

\section{Digenea Allocreadiidae Creptotrema lynchi sp. n. (Figs. 1-3)}

Description (based on 20 specimens): Body oval to elongate, 0.85 to $1.49 \mathrm{~mm}$ long by 0.39 to 0.67 $\mathrm{mm}$ wide; widest at midbody. Tegument thin, aspinous. Oral sucker subterminal, 156 to 276 long by 192 to 336 wide, with 2 small dorsolateral papillae. Prepharynx short; pharynx 60 to 84 long by 120 wide; ceca extend near posterior end of body. Acetabulum 1/4 body length from anterior end, 264 to 396 long by 276 to 372 wide. Testes in posterior third of body, elongate, symmetrical

Received for publication 23 September 1975.

* Funds for this study were provided through a grant from the National Geographic Society to Dr. Thomas B. Thorson, University of NebraskaLincoln. to slightly oblique; left testis 300 to 480 long by 192 to 252 wide, right testis 325 to 540 long by 180 to 265 wide. Cirrus sac dorsolateral to acetabulum, 444 to 660 long by 84 to 108 wide; bipartite seminal vesicle, pars prostatica, and eversible cirrus present; cirrus 150 by 42 , unarmed. Genital pore median, anteroventral to cecal bifurcation. Short metraterm present (not apparent in holotype); uterus short, looping between testes and acetabulum; loops may extend extracecally. Ovary posterolateral to acetabulum, posterior to cirrus sac, 204 to 264 long by 216 to 288 wide. Vitellaria follicular, extracecal, follicles large, from level of pharynx to posterior end of body; few intercecal follicles may be present. Vitelline receptacle median, posterodorsal to ootype; seminal receptacle present; Mehlis' gland present, Laurer's canal not observed. Slightly collapsed mature uterine eggs 55 to 67 long by 35 to 38 wide. Excretory pore terminal; vesicle I-shaped, may extend to anterior margin of testes.

Host: Bufo marinus L.

Site: At base of villi in middle portion of small intestine.

Locality: $1 \mathrm{~km}$ north of San Cristobal, Atlantico, Colombia.

Holotype: USNM Helm. Coll. No. 73484.

Paratypes: USNM Helm. Coll. No. 73485; Univ. Neb. State Mus., H. W. Manter Lab. No. 20251.

\section{Remarks}

Manter (1962) showed that Creptotrema funduli Mueller 1934 and C. muelleri Coil and Kuntz 1960 did not belong in the genus Creptotrema, leaving C. creptotrema Travassos et al. 1928 the only member. Travassos et al. (1928) described C. creptotrema as possessing a spinous tegument and cirrus sac, 

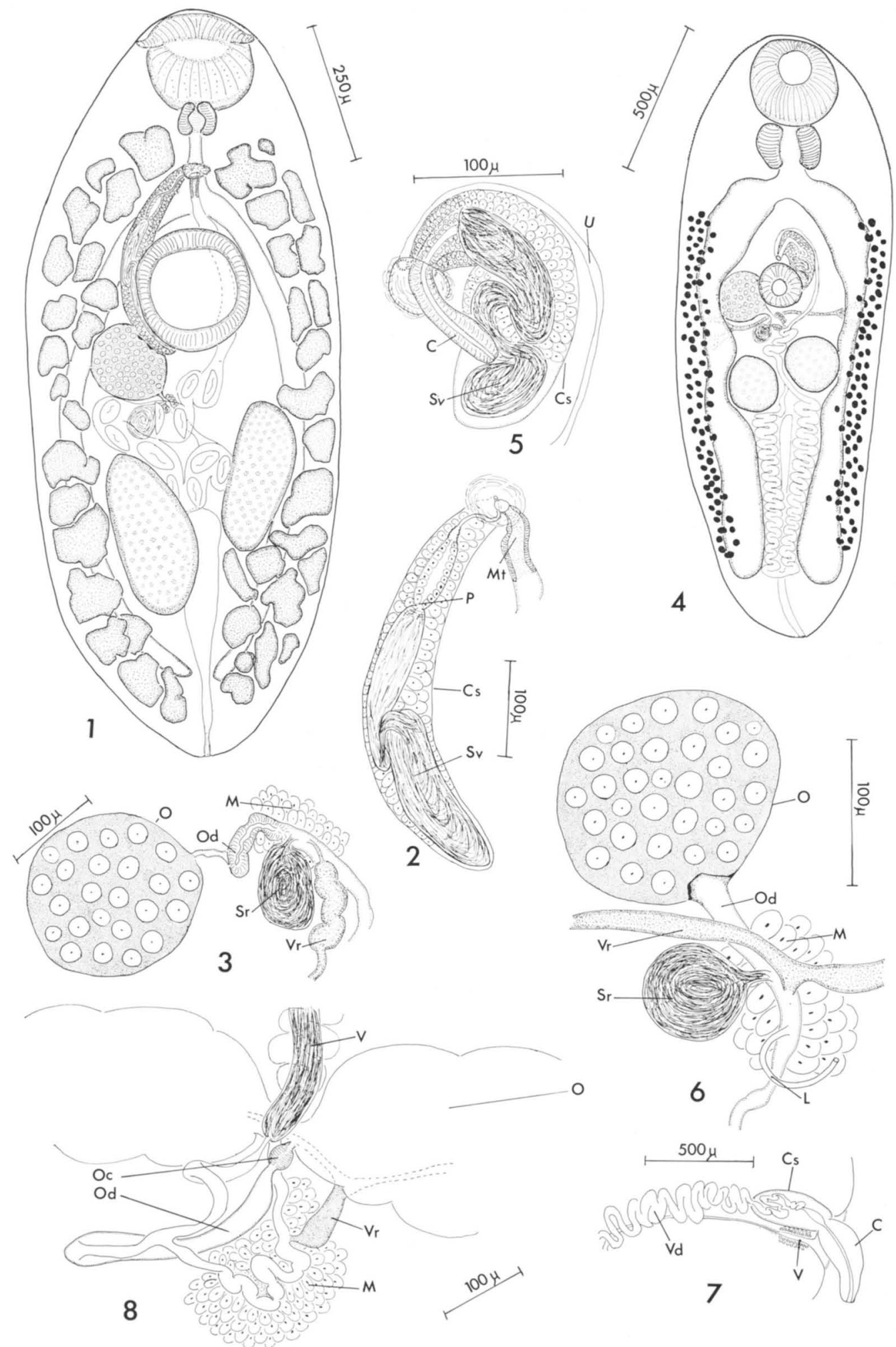
but did not figure the latter distinctly. Manter (1962) cited the presence of tegumental spines and probable absence of a cirrus sac as reasons for removing the genus to the family Lepocreadiidae, subfamily Homalometrinae. Since a cirrus sac was described, and since subsequent reports of $C$. creptotrema have not mentioned tegumental spines, I believe that Creptotrema should be retained in the Allocreadiidae, and the new species allocated to the genus.

Creptotrema lynchi differs from C. creptotrema in possessing elongate rather than spherical testes, suckers which are much smaller relative to body size, relatively much smaller oral papillae, and slightly smaller eggs. Creptotrema lynchi is the third species of allocreadiid known to regularly parasitize amphibians. The others are Bunoderella metteri Schell 1964 in Ascaphus truei (Anura: Ascaphidae) and Allocreadium pseudotritoni Rankin 1937 in Pseudotriton m. montanus and P. r. ruber (Caudata: Plethodontidae) in North America.

The species is named in honor of Dr. John D. Lynch, University of Nebraska-Lincoln, noted systematist of Neotropical anurans.

\section{Gorgoderidae \\ Gorgoderina diaster Lutz 1926}

Two specimens of this species were collected from each of two B. marinus captured $15 \mathrm{~km}$ west of Neiva, Huila, Colombia. The four specimens agreed with the original description of $G$. diaster except that the sucker ratio ranged from $1: 1.35$ to 1.60 as opposed to $1: 1.3$. Fernandes (1958) reported $G$. diaster from Rana palmipes and Pseudis paradoxa (type host) from Maracay, Venezuela (type locality). Bufo marinus is a new host record and Colombia is a new locality for $G$. diaster. Two specimens have been deposited in the Manter Lab. No. 20250.

\section{Macroderoididae \\ Glypthelmins robustus sp. n. \\ (Figs. 4-6)}

Description (based on 2 specimens): Body elongate, 1.96 to $2.30 \mathrm{~mm}$ long by 0.66 to 0.74 $\mathrm{mm}$ wide, widest at level of cecal bifurcation. Tegument 5 to 10 thick, spinose anteriorly to level of pharynx. Oral sucker subterminal, 264 long by 288 to 300 wide. Prepharynx short; pharynx 144 to 156 long by 204 to 216 wide. Acetabulum 35 to $39 \%$ body length from anterior end, 156 long by 145 wide. Esophagus extremely short; ceca extend to within 4 to $9 \%$ body length of posterior end, lined with prominent epithelial cells. Testes intercecal, slightly oblique, at midbody; anterior testis 192 to 204 long by 180 to 204 wide, posterior testis 192 to 216 long by 180 to 216 wide. Cirrus sac anterodorsal to acetabulum, 372 to 384 long by 121 to 192 wide, containing coiled seminal vesicle and eversible cirrus surrounded by prostatic cells; cirrus 108 to 156 long by 60 wide, unarmed. Genital pore median, immediately preacetabular. Uterus extending posteriorly to cecal tips, with ascending and descending intercecal loops posterior to testes, and few weakly developed loops anterior to testes. Ovary dorsolateral to acetabulum, pretesticular, 144 to 168 in diameter. Seminal receptacle posterior to ovary; Mehlis' gland and Laurer's canal present. Vitellaria follicular, extracec'al, follicles extending from near cecal tips to level of bifurcation; transverse vitelline ducts passing dorsal to ceca, reservoir anterodorsal to ootype. Eggs 23 to 26 long by 12 wide. Excretory vesicle I-shaped, extending to near posterior margin of posterior testis; pore terminal.

Host: Bufo marinus L.

Site: Upper small intestine.

Locality: $15 \mathrm{~km}$ west of Neiva, Huila, Colombia.

Holotype: USNM Helm. Coll. No. 73482.

Paratype: USNM Helm. Coll. No. 73483.

\section{Remarks}

Five species of Glypthelmins possess a pharynx which is as large as the acetabulum: G. facioi Brenes Madrigal et al. 1959, G.

$\leftarrow$

Figures 1-3. Creptotrema lynchi. 1. Ventral view of holotype. 2. Terminal genitalia. 3. Ootype region.

Figures 4-6. Glypthelmins robustus. 4. Ventral view of holotype. 5. Terminal genitalia. 6. Ootype region.

Figures 7, 8. Ophotaenia bonariensis. 7. Terminal genitalia. 8. Ootype region.

Abbreviations: C, cirrus; Cs, cirrus sac; L, Laurer's canal; M, Mehlis' gland; O, ovary; Oc, oocapt; Od, oviduct; P, pars prostatica; $\mathrm{Sr}$, seminal receptacle; V, vagina; Vd, vas deferens; Vr, vitelline reservoir. 
palmipedis (Lutz 1928) Teixeira de Freitas 1941, G. californiensis (Cort 1919) Miller 1930, G. shastai Ingles 1932, and G. quieta (Stafford 1900) Stafford 1905. In all cases, the pharynx and acetabulum are subequal. Brooks (1976) has shown in a study of 273 specimens of G. quieta that the pharynx: acetabulum ratio varies from 1:0.92 to 1.0. In these five species, the oral sucker is approximately twice the size of the acetabulum, as in G. robustus. Thus, the oral sucker: pharynx:acetabulum ratio of $4: 3: 2$ for $G$. robustus is markedly different from the $2: 1: 1$ ratio for the other above-mentioned species. Glypthelmins robustus further resembles G. palmipedis in possessing diagonal testes and an extremely short esophagus and G. facioi in possessing an I-shaped excretory vesicle. Both G. palmipedis and G. facioi have slightly larger eggs than G. robustus and are spined over the entire body (those of G. facioi are partially fused to give the appearance of scales).

\section{Cestoidea \\ Family Nematotaeniidae \\ Cylindrotaenia americana Jewell 1916}

Over 100 specimens of this species were collected from 19 of the 27 B. marinus examined $(70 \%)$. Toads infected with this species were found at the San Cristobal and Neiva localities as well as along the Quebrada Doña Juana in the vicinity of La Dorada, Department of Caldas. According to Wardle and MacLeod (1952) this species has been reported in Leptodactylus ocellatus in Brazil and Argentina as well as in a variety of anurans in North America. Bufo marinus is a new host and Colombia a new locality for C. americana. Specimens have been deposited in the Univ. Neb. State Museum, H. W. Manter Lab. No. 20258.

\section{Family Proteocephalidae \\ Ophiotaenia bonariensis Szidat and Soria 1954 (Figs. 7, 8)}

A single intact specimen of this species was found in a specimen of $B$. marinus collected $1 \mathrm{~km}$ north of San Cristobal, Department of Atlanticó. No description or illustration of the terminal genitalia or ootype region was given in the original description, but are figured here. My specimen also differs from the information given by Szidat and Soria (1954) in possessing a scolex which is as wide $(800 \mu \mathrm{m})$ as originally described, but is not wider than the neck, the vagina anterior or posterior to the cirrus sac, 140 to 155 testes rather than 120 to 140 , and 34 to 46 uterine branches rather than 46 to 54 . Ophiotaenia bonariensis was originally described from Leptodactylus ocellatus in Argentina. Rêgo (1962) reported O. bonariensis from L. ocellatus, $L$. pentadactylus, and Bufo marinus from Brazil. Colombia is a new locality for the species. Thirteen slides containing the entire specimen have been deposited in the Univ. Neb. State Museum, H. W. Manter Lab. No. 20257.

\section{DISCUSSION}

This report brings to six the number of platyhelminths known from Colombian amphibians. Uribe-Piedrahita (1948) reported Haematoloechus medioplexus Stafford 1902, a common North American species from Rana palmipes. Cylindrotaenia americana is also known from North and South America. Ophiotaenia bonariensis and Gorgoderina diaster are known only from South America, and Creptotrema lynchi belongs to a genus whose only other member is known only from South America. Glypthelmins robustus resembles both G. facioi from Costa Rica and G. palmipedis from Venezuela and Brazil. Despite our limited knowledge of the amphibian helminthofauna of Colombia, it is apparent that it consists of species with both North and Central as well as South American affinities.

\section{ACKNOWLEDGMENTS}

The author expresses appreciation to Drs. John D. Lynch for his aid in identifying hosts, Robin M. Overstreet and Mary H. Pritchard for their help in the study of the worms, and Thomas B. Thorson for providing the opportunity to study in Colombia.

\section{LITERATURE CITED}

Brooks, D. R. 1976. Parasites of amphibians of the Great Plains. II. Platyhelminths of amphibians in Nebraska. Bull Univ Nebr State Mus. 10: 65-92.

Fernandes, J. C. 1958. Notas sobre algumas especies do genero Gorgoderina Looss 1902 
(Gorgoderidae). Mem Inst Oswaldo Cruz 56: 1-15.

Manter, H. W. 1962. Notes on the taxonomy of certain digenetic trematodes of some American freshwater fishes. Proc Helminthol Soc Wash 29: 97-102.

RÊGo, A. A. 1962. Ocorrência de "Ophiotaenia bonariensis" Szidat \& Soria, 1954 em anfíbios anuros (Cestoda, Proteocephalidea). Rev Bras Biol 22: 377-380.

Szidat, L., And M. F. Soria. 1954. Nuevos parasitos de Leptodactylus ocellatus (L.) de Ja
Republica Argentina. Comun Inst Nac Invest Cienc Nat Cience Zool 2 : 189-210.

Travassos, L., P. Artigas, and C. Pereira. 1928. Fauna helmintologica dos peixes de agua doce do Brasil. Arch Inst Biol defesa Agric e Animal 1: 5-68.

Uribe-Piedrahita, C. 1948. Contribuciones al estudio de la parasitología en Colombia. Caldasia 4: 649-653.

Wardle, R. A., And J. A. MacLeod. 1952. The Zoology of Tapeworms. Univ Minn Press, $780 \mathrm{p}$. 